\title{
Analisis Nilai Ekspor Kopi Provinsi Bali dan Faktor-faktor yang Mempengaruhinya
}

\author{
SAUMIA KRISNA DEVI DASI, I MADE SUDARMA, \\ IDA AYU LISTIA DEWI \\ Program Studi Agribisnis, Fakultas Pertanian, Universitas Udayana \\ Jalan PB. Sudirman Denpasar 80232 \\ Email: saumia82@gmail.com \\ sudarmaimade@yahoo.com
}

\begin{abstract}
Analysis of Coffee Export Value of Bali Province and Its Affecting Factors

This research aims to find out how much the contribution of coffee exports to the GDP of the agricultural sector of Bali Province, to know the factors that affect the value of coffee exports of Bali Province and to know the trend and the trend forecast of coffee export value for the next five years. This research was conducted in Bali Province using secondary data derived from government agencies. Data were analyzed based on contributions theory, multiple linear regression analysis and trend analysis. The results showed that the average contribution of coffee export of Bali Province to GDP of agriculture of Bali Province is $17,41 \%$. The result of factors that estimated in this research stated that all significant factor to coffee export value of Bali Province is $72,3 \%$ and the remaining $27,7 \%$ is explained by other factors outside the study. Factors that partially significantly affect the value of coffee exports are coffee export volume of Bali province, world coffee price and US dollar exchange rate. Trend and forecasting export value of Bali Province coffee is projected to increased in the next five years, which is 2016 to 2020. Suggestions that can be given is increaseing export volume is very important to do because the export volume is the most influental factor on export coffee value, so it needs to be done product quality improvement and network marketing expansion.
\end{abstract}

Keywords: coffee, export value, trend

\section{Pendahuluan}

\subsection{Latar Belakang}

Perdagangan luar negeri terutama ekspor, sangat penting peranannya dalam perekonomian Indonesia karena devisa yang diperoleh dari kegiatan ekspor merupakan salah satu sumber pembiayaan pembangunan. Tujuan dari program pengembangan ekspor adalah mendukung upaya peningkatan daya saing global produk serta meningkatkan peranan ekspor dalam memacu pertumbuhan ekonomi Indonesia.

Perkembangan ekspor non migas memiliki makna strategis bagi perekonomian nasional. Keberhasilan meningkatkan ekspor non migas mencerminkan peningkatan daya saing nasional sekaligus merupakan salah satu indikasi timbulnya dinamika 
postif dalam kewirausahaan di tanah air. Demi kepentingan pembangunan maka peranan ekspor perlu ditingkatkan terutama melalui ekspor non migas (Basri, 1995).

Pertanian merupakan salah satu sektor yang menghasilkan komoditas ekspor non migas. Sektor pertanian Bali kembali menjadi perhatian, tidak sedikit kalangan dan praktisi yang beranggapan bahwa pertanian bisa menjadi pilar pendukung utama bagi perekonomian Bali. Dewasa ini, sektor pertanian Bali memperlihatkan kecendrungan yang menurun dalam perannya sebagai sektor pembentuk Produk Domestik Regional Bruto (PDRB) Provinsi Bali.

Sektor pertanian di Provinsi Bali terdiri dari beberapa subsektor. Perkebunan merupakan salah satu sub sektor potensial yang menghasilkan komoditi ekspor non migas. Kopi merupakan salah satu komoditi ekspor unggulan hasil perkebunan. Menurut Ditjenbun (2013), kopi merupakan komoditas perkebunan yang memegang peranan penting dalam perekonomian Indonesia. Komoditas ini menjadi sumber pendapatan utama petani dari kurang lebih 1,97 juta KK yang tersebar di seluruh wilayah Indonesia.

Komoditas kopi Provinsi Bali merupakan salah satu komoditas perkebunan yang diperdagangkan baik secara nasional maupun internasional. Komoditas kopi adalah salah satu komoditas budidaya perkebunan yang diunggulkan, karena komoditas ini memiliki nilai ekonomis tinggi serta prospek yang cerah. Menurut data lima tahun terakhir, produksi kopi Provinsi Bali mengalami fluktuasi dari tahun ke tahun. Produksi kopi Provinsi Bali tertinggi terjadi di tahun 2012 yaitu sebesar 18.880,430 ton. Produksi terendah terjadi di tahun 2014 yaitu sebesar 15.920,680 ton, namun kembali meningkat di tahun 2015 menjadi 17.340,820 ton. Tingginya produksi kopi Provinsi Bali nyatanya tidak selalu meningkatkan volume kopi yang di ekspor begitupula terhadap nilainya.

Tabel 1.

Volume dan Nilai Ekspor Komoditas Kopi Provinsi Bali Tahun $2011-2015$

\begin{tabular}{ccrr}
\hline No & Tahun & Volume (Ton) & \multicolumn{1}{c}{ Nilai (US\$) } \\
\hline 1 & 2011 & 30,295 & $215.074,12$ \\
2 & 2012 & 19,081 & $207.731,38$ \\
3 & 2013 & 35,352 & $205.309,07$ \\
4 & 2014 & 240,765 & $1.233 .628,66$ \\
5 & 2015 & 5,303 & $143.160,48$ \\
\hline
\end{tabular}

Sumber: Disperindag Provinsi Bali, 2016

Data volume dan nilai ekspor kopi Provinsi Bali selama lima tahun terakhir menunjukan terjadi fluktuasi terhadap volume maupun nilai ekspor kopi Bali dimana pada tahun 2014 total volume ekspor mencapai 240 ton dengan nilai ekspor US\$1,2 juta. Volume ekspor tersebut meningkat dari tahun 2013 yang tercatat sebesar 36 ton dengan nilai ekspor US\$205 ribu, namun pada tahun 2015 volume dan nilai ekspor 
kopi Provinsi Bali mengalami penurunan drastis menjadi 5 ton dengan nilai ekspor US\$143 ribu.

Pada semester pertama di tahun 2016, Bali mengantongi devisa sebesar US\$60.131,42 dari kegiatan ekspor kopi. Penjualan tersebut merosot 57,34\% dibanding semester yang sama di tahun sebelumnya yaitu US\$ 140.940,48. Pengapalan komoditas kopi nyatanya meningkat sebesar 146,22\% dari 5,15 ton pada semester pertama tahun 2015 menjadi 12,68 ton pada semester pertama di tahun 2016 (Disperindag Provinsi Bali, 2016).

Fluktuasi nilai ekspor kopi Provinsi Bali yang signifikan menunjukan adanya faktor-faktor yang mempengaruhi nilai ekspor kopi itu sendiri. Nilai jual kopi di dunia internasional yang tinggi serta kontribusinya terhadap devisa daerah Bali mencerminkan bahwa komoditas kopi masih menunjukan potensi yang menjanjikan untuk ditekuni dan dijalankan baik dalam dunia usaha (eksportir kopi) maupun petani kopi yang berorientasi ekspor di Provinsi Bali.

Berdasarkan data aktual yang ada, perkembangan ekspor kopi Provinsi Bali yang sempat meningkat namun menurun di tahun terakhir ini merupakan kondisi yang perlu dianalisis lebih dalam agar eksistensi dari komoditas kopi Provinsi Bali dapat dimanfaatkan sebagai pemenuhan kebutuhan kegiatan ekonomi.

\subsection{Tujuan Penelitian}

Berdasarkan dari latar belakang dan rumusan masalah diatas, maka penelitian ini bertujuan:

1. Untuk mengetahui seberapa besar kontribusi ekspor kopi terhadap PDRB sektor pertanian Provinsi Bali.

2. Untuk menganalisis faktor-faktor yang mempengaruhi nilai ekspor kopi Provinsi Bali.

3. Untuk menganalisis trend dan proyeksi ekspor kopi Provinsi Bali.

\section{Metode Penelitian}

\subsection{Lokasi dan Waktu Penelitian}

Penelitian ini dilaksanakan di Provinsi Bali. Pemilihan lokasi ini dipilih dengan metode purposive. Penelitian dilaksanakan pada bulan November 2016 hingga bulan Mei 2017.

\subsection{Jenis dan Sumber Data}

Ditinjau dari jenisnya, data yang digunakan dalam penelitian ini adalah data kualitatif dan kuantitatif. Data kualitatif berupa teks, gambar, penjelasan umum mengenai daerah atau lokasi penelitian. Sedangkan data kuantitatif merupakan data berupa angka-angka diantaranya data PDRB sektor petanian, nilai ekspor kopi, volume ekspor kopi, produksi kopi, harga kopi dunia, harga kopi domestik dan kurs dollar Amerika Serikat. Menurut sumbernya, data yang digunakan dalam penelitian ini adalah data sekunder. Data sekunder adalah informasi tangan kedua yang sudah 
dikumpulkan oleh beberapa orang (organisasi) untuk tujuan tertentu dan tersedia untuk berbagai penelitian (Riadi, 2015).

\subsection{Teknik Pengumpulan Data, Konsep dan Indikator Penelitian}

Teknik pengumpulan data yang digunakan dalam penelitian ini adalah analisis dokumen dan pencatatan. Konsep yang digunakan dalam penelitian ini ada tiga yaitu kontribusi ekspor kopi terhadap PDRB sektor Pertanian Provinsi Bali, faktor-faktor yang mempengaruhi nilai ekspor kopi Provinsi Bali serta trend dan proyeksi nilai ekspor kopi Provinsi Bali. Indikator-indikator yang digunakan adalah PDRB sektor pertanian Provinsi Bali, nilai ekspor kopi Provinsi Bali, volume ekspor kopi Provinsi Bali, produksi kopi Provinsi Bali, harga kopi dunia, harga kopi domestik, kurs dollar AS dan waktu (t).

\subsection{Metode Analisis Data}

Rumusan masalah pertama yaitu kontribusi ekspor kopi Provinsi Bali terhadap PDRB sektor pertanian Provinsi Bali, diselesaikan dengan membandingkan nilai ekspor kopi Provinsi Bali dengan PDRB sektor pertanian Provinsi Bali yaitu menggunakan rumus matematis berikut (Kartika, 2012).

$$
\text { Kontribusi Ekspor Kopi Tahun-t }(\%)=\frac{\text { Nilai Ekspor kopi Tahun-t }}{\text { PDRB Sektor Pertanian Tahun-t }} \times 100 \% \ldots(1)
$$

Rumusan masalah kedua diselesaikan dengan analisis regresi linier berganda. Menurut Gujarati (2001) model regresi berganda merupakan model regresi dengan lebih dari satu variabel penjelas atau dapat diartikan terdapat lebih dari satu variabel penjelas (independent) yang mempengaruhi variabel tak bebas (dependent). Metode yang digunakan adalah metode kuadrat terkecil (OLS) sedangkan operasional pengolahan data dilakukan dengan bantuan software IBM SPSS Version 21. Hubungan nilai ekspor dengan faktor-faktor yang mempengaruhinya dinyatakan dalam persamaan regresi linear berganda yaitu:

$$
\mathrm{Y}=\alpha+\beta 1 \mathrm{X} 1+\beta 2 \mathrm{X} 2+\beta 3 \mathrm{X} 3+\beta 4 \mathrm{X} 4+\beta 5 \mathrm{X} 5+\mu .
$$

Keterangan:

$\mathrm{Y} \quad=$ nilai ekspor kopi Provinsi Bali $(\mathrm{Rp})$

$\mathrm{X} 1=$ volume ekspor kopi Provinsi Bali $(\mathrm{Kg})$

$\mathrm{X} 2=$ produksi kopi Provinsi bali $(\mathrm{Kg})$

$\mathrm{X} 3=$ harga kopi dunia (US\$/Kg)

$\mathrm{X} 4 \quad=$ harga kopi domestik $(\mathrm{Rp} / \mathrm{Kg})$

$\mathrm{X} 5=$ kurs dollar Amerika (Rp/US\$)

$\mu \quad=$ Random error

$\alpha=$ Konstanta intersep

ß1-ß6 = Koefisien Regresi Variabel

Rumusan masalah terakhir mengenai perkembangan atau trend dan proyeksi nilai ekspor kopi Provinsi Bali diselesaikan dengan analisis trend menggunakan data 
selama 20 tahun terakhir. Pengolahan analisis trend menggunakan software Minitab 14. Pemilihan model pada analisis trend (Linear, Kuadratik, Pertumbuhan eksponensial dan S-Curve) didasarkan pada nilai error MSD, MAD dan MAPE. Semakin kecil nilai mada MSD, MAD dan MAPE menunjukan tingkat error yang semakin rendah (Santoso, 2009).

\section{Hasil dan Pembahasan}

\subsection{Kontribusi Ekspor Kopi Terhadap PDRB Sektor Pertanian Provinsi Bali}

Hasil penelitian menunjukan bahwa rata-rata kontribusi nilai ekspor kopi terhadap PDRB sektor Pertanian Provinsi Bali adalah sebesar 17,41\%. Selama periode tahun 1996 s.d 2015, kontribusi nilai ekspor tertinggi terjadi di tahun 1998 yaitu sebesar 91,97\%. Tingginya kontribusi nilai ekspor kopi pada saat itu disebabkan oleh perkembangan ekspor kopi yang sangat tinggi serta menurunnya ekspor pada komoditas pertanian lainnya. Selama periode tahun 1996 s.d 2000, terjadi krisis moneter yang sangat parah yang menimpa hampir seluruh kawasan Asia Timur. Indonesia, Korea Selatan, dan Thailand adalah negara-negara yang terkena dampak krisis terparah. Akibat adanya krisis tersebut, rupiah mengalami depresiasi sehingga tingginya kurs dollar Amerika Serikat pada saat itu, menyebabkan nilai ekspor kopi yang diterima Provinsi Bali sangat besar. Selengkapnya dapat dilihat pada Tabel 2 dibawah ini.

Penurunan kontribusi tertinggi terjadi di tahun 2002 dengan penurunan kontribusi sebesar 22,91\% dari tahun sebelumnya. Hal tersebut disebabkan oleh menurunya kegiatan ekspor kopi secara drastis akibat terhentinya pengiriman kopi ke mancanegara. Pada saat tersebut terjadi ketebatasan produksi kopi yang diakibatkan oleh serangan busuk batang pada tanaman kopi di seluruh areal perkebunan Provinsi Bali. 
Tabel 2.

Kontribusi Nilai Ekspor Kopi Terhadap PDRB Sektor Pertanian Provinsi Bali Tahun

\begin{tabular}{cccr}
\multicolumn{4}{c}{$1996-2015$} \\
Tahun & $\begin{array}{c}\text { PDRB pertanian atas dasar harga } \\
\text { berlaku } \\
\text { (Rp) }\end{array}$ & $\begin{array}{c}\text { Nilai ekspor kopi Provinsi } \\
\text { Bali } \\
(\text { Rp) }\end{array}$ & $\begin{array}{c}\text { Kontribusi } \\
(\%)\end{array}$ \\
\hline 1996 & $1.926 .570 .520,00$ & 379.458 .395 & 19,70 \\
1997 & $2.913 .137 .290,00$ & $504.770 .701,38$ & 17,33 \\
1998 & $3.982 .370 .060,00$ & $3.662 .503 .661,59$ & 91,97 \\
1999 & $3.811 .018 .180,00$ & $1.495 .403 .525,54$ & 39,24 \\
2000 & $3.903 .268 .560,00$ & $2.152 .875 .491,32$ & 55,16 \\
2001 & $4.420 .565 .540,00$ & $1.177 .017 .775,11$ & 26,63 \\
2002 & $5.235 .587 .420,00$ & $194.598 .121,69$ & 3,72 \\
2003 & $5.666 .835 .820,00$ & $104.931 .128,61$ & 1,85 \\
2004 & $6.011 .426 .770,00$ & $179.033 .767,55$ & 2,98 \\
2005 & $6.887 .173 .890,00$ & $208.992 .764,14$ & 3,03 \\
2006 & $7.463 .262 .780,00$ & $465.986 .774,86$ & 6,24 \\
2007 & $8.216 .473 .400,00$ & $719.055 .265,53$ & 8,75 \\
2008 & $9.152 .614 .120,00$ & $775.853 .489,15$ & 8,48 \\
2009 & $10.538 .416 .002,00$ & $1.632 .608 .782,33$ & 15,49 \\
2010 & $12.371 .295 .010,00$ & $728.112 .235,15$ & 5,89 \\
2011 & $15.284 .290 .000,00$ & $1.305 .865 .644,55$ & 8,54 \\
2012 & $18.518 .180 .000,00$ & $859.073 .938,94$ & 4,64 \\
2013 & $20.450 .710 .000,00$ & $2.171 .077 .512,99$ & 10,62 \\
2014 & $22.899 .520 .000,00$ & $2.438 .722 .726,18$ & 10,65 \\
2015 & $26.439 .130 .000,00$ & $1.917 .200 .853,35$ & 7,25 \\
\hline Jumlah & $196.091 .845 .362,00$ & $23.073 .142 .554,58$ & 348,14 \\
Rata-rata & $9.804 .592 .268,10$ & $1.153 .657 .127,73$ & 17,41 \\
\hline Sumber & BPS Pro & & \\
\hline
\end{tabular}

Sumber: BPS Provinsi Bali, Disperindag Provinsi Bali, 1996-2015 (diolah)

\subsection{Faktor-faktor yang Mempengaruhi Nilai Ekspor Kopi Provinsi Bali}

Berdasarkan hasil penelitian didapatkan fungsi regresi sebagai berikut:

$\mathrm{LnY}=-15,103+0,312 \ln \mathrm{X} 1+0,198 \ln \mathrm{X} 2+1,059 \ln \mathrm{X} 3-0,038 \ln \mathrm{X} 4+$ $2,124 \ln \mathrm{X} 5$

Nilai Adjusted $\mathrm{R}^{2}$ sebesar 0,723 berarti variabel-variabel volume ekspor kopi Provinsi Bali, produksi kopi Provinsi Bali, harga kopi dunia, harga kopi domestik, dan kurs dollar AS secara bersama-sama mampu menjelaskan perubahan yang terjadi pada nilai ekspor kopi Provinsi Bali sebesar 72,3\%.

Secara bersama-sama semua faktor berpengaruh nyata terhadap nilai ekspor kopi Provinsi Bali. Secara parsial faktor-faktor yang berpengaruh nyata terhadap nilai ekspor kopi Provinsi Bali adalah volume ekspor kopi, harga kopi dunia dan kurs dollar AS. Berdasarkan besarnya koefisien beta, faktor yang paling berpengaruh terhadap nilai ekspor adalah volume ekspor kopi Provinsi Bali. Selengkapnya, dapat dilihat pada Tabel 3 dibawah ini. 
Tabel 3.

Hasil Analisis Regresi Faktor-faktor yang Mempengaruhi Nilai Ekspor Kopi

Provinsi Bali

\begin{tabular}{|c|c|c|c|c|c|}
\hline Variabel Bebas & $\begin{array}{c}\text { Koefisien } \\
\text { Regresi }\end{array}$ & $\begin{array}{l}\text { Std. } \\
\text { Error }\end{array}$ & Beta & t hitung & Signifikan \\
\hline Constant & $-15,103$ & 11,741 & & $-1,286$ & 0,219 \\
\hline $\operatorname{lnX} 1$ = Volume ekspor kopi & 0,312 & 0,09 & 0,55 & 3,488 & 0,004 \\
\hline $\ln \mathrm{X} 2=$ Produksi Kopi & 0,198 & 0,895 & 0,045 & 0,221 & 0,828 \\
\hline $\operatorname{lnX} 3$ = Harga kopi dunia & 1,059 & 0,411 & 0,543 & 2,575 & 0,022 \\
\hline $\operatorname{lnX} 4=$ Harga kopi domestik & $-0,038$ & 0,411 & $-0,017$ & $-0,093$ & 0,927 \\
\hline $\operatorname{lnX} 5=$ kurs dollar AS & 2,124 & 0,859 & 0,393 & 2,473 & 0,027 \\
\hline $\mathrm{R}^{2} \quad=0,796$ & & & & & \\
\hline \\
\hline \multicolumn{6}{|l|}{$\begin{array}{l}\text { Adjusted } \mathrm{R}^{2}=0,723 \\
\text { F Hitung } \quad=10,922\end{array}$} \\
\hline \multicolumn{6}{|l|}{ F Tabel $=2,958$} \\
\hline \multicolumn{6}{|l|}{$\mathrm{T}$ Tabel $=2,145$} \\
\hline \multicolumn{6}{|c|}{ Keterangan : - tidak nyata pada taraf kepercayaan $95 \%$} \\
\hline
\end{tabular}

\subsection{Trend dan Proyeksi Ekspor Kopi Provinsi Bali}

A. Trend dan Proyeksi Nilai Ekspor Kopi Provinsi Bali

Berdasarkan Gambar 1, terlihat bahwa trend nilai ekspor kopi Provinsi Bali cenderung mengalami peningkatan pada periode tahun 1996 sampai tahun 2015.

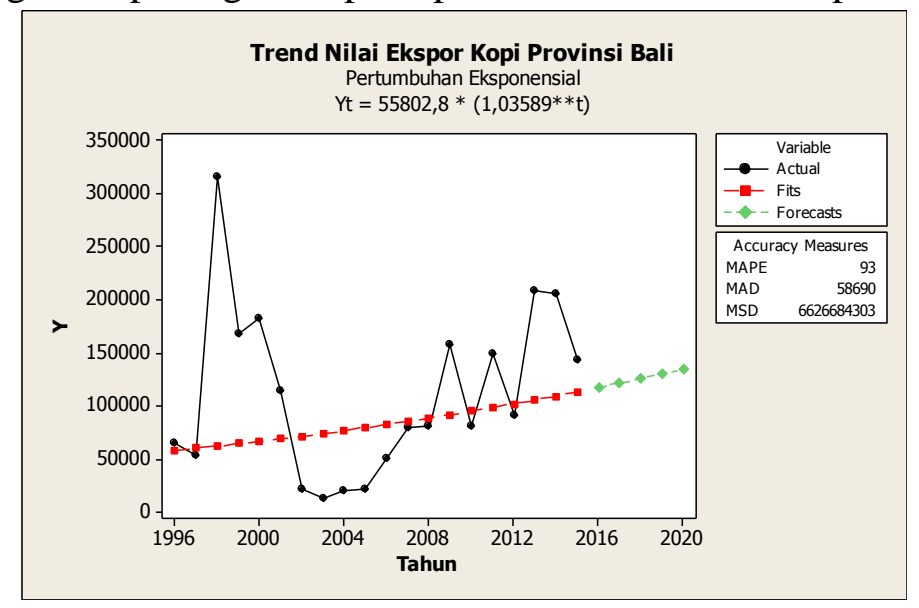

Gambar 1.

Trend dan Proyeksi Nilai Ekspor Kopi Provinsi Bali

Hasil proyeksi untuk lima tahun kedepan yaitu tahun 2016 s.d 2020, nilai ekspor kopi Provinsi Bali diproyeksikan akan mengalami sedikit peningkatan.

B. $\quad$ Trend dan proyeksi volume ekspor kopi Provinsi Bali

Berdasarkan Gambar 2, terlihat bahwa trend volume ekspor kopi Provinsi Bali cenderung mengalami penurunan pada periode tahun 1996 sampai tahun 2015. 


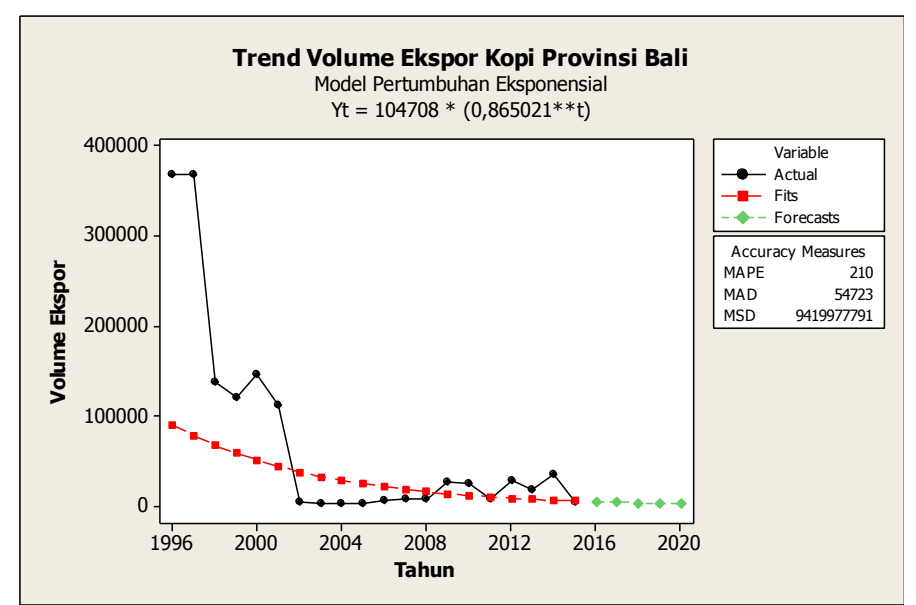

Gambar 2.

Trend dan Forecasting Volume Ekspor Kopi Provinsi Bali

Jika diproyeksikan dalam kurun waktu lima tahun kedepan, yaitu dari tahun 2016 s.d 2020, trend volume ekspor kopi Provinsi Bali ke dunia akan cenderung menurun.

\section{Trend dan Proyeksi Harga Kopi Dunia}

Berdasarkan grafik analisis trend pada Gambar 3, menunjukan terjadi fluktuasi harga kopi dunia selama periode penelitian yaitu 1996 s.d 2015.

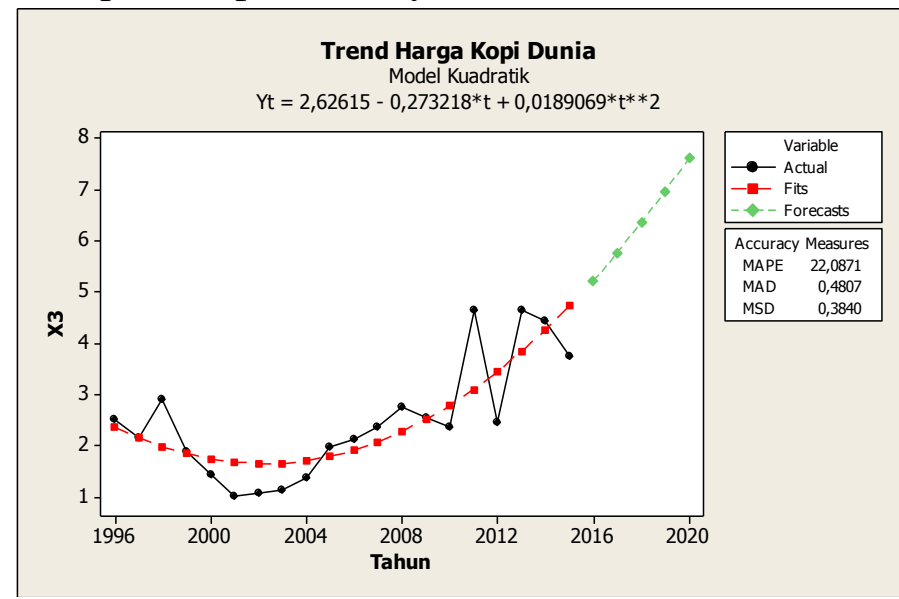

Gambar 3.

Trend dan Forecasting Harga Kopi Dunia

Apabila diproyeksikan dalam jangka waktu lima tahun mendatang yaitu tahun 2016 s.d 2020, harga kopi dunia akan cenderung mengalami peningkatan.

\section{Trend dan Proyeksi Kurs Dollar Amerika Serikat}

Berdasarkan grafik pada Gambar 5, nilai tukar rupiah terhadap dollar mengalami fluktuasi dari tahun 1996 s.d 2015. 


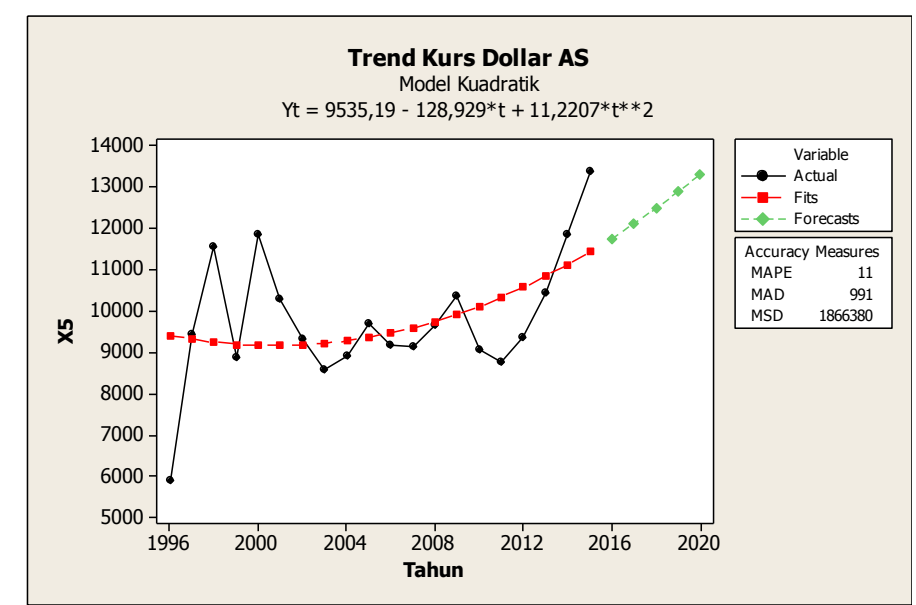

Gambar 4.

Trend dan Forecasting Kurs Dollar AS

Apabila diproyeksikan dalam jangka waktu lima tahun mendatang yaitu tahun 2016 s.d 2020, nilai tukar rupiah terhadap dollar akan cenderung mengalami peningkatan.

\section{Simpulan dan Saran}

\subsection{Simpulan}

Rata-rata kontribusi nilai ekspor kopi terhadap PDRB sektor pertanian setiap tahunya adalah sebesar $17,41 \%$. Hasil dari faktor-faktor yang diestimasikan terhadap penelitian ini menyatakan bahwa secara bersama-sama semua faktor berpengaruh nyata terhadap nilai ekspor kopi Provinsi Bali. Faktor-faktor yang secara parsial berpengaruh nyata terhadap nilai ekspor kopi adalah volume ekspor kopi Provinsi Bali, harga kopi dunia, dan kurs dollar AS. Faktor yang mempunyai pengaruh paling besar terhadap nilai ekspor kopi Provinsi Bali adalah volume ekspor kopi Provinsi Bali. Trend dan forecasting nilai ekspor kopi Provinsi Bali diproyeksikan cenderung mengalami sedikit peningkatan dalam kurun waktu lima tahun kedepan. Volume ekspor kopi Provinsi Bali diproyeksikan menurun, harga kopi dunia dan kurs dollar Amerika Serikat diproyeksikan akan mengalami peningkatan untuk lima tahun ke depan.

\subsection{Saran}

Volume ekspor kopi Provinsi Bali merupakan faktor yang paling berpengaruh terhadap nilai ekspor, sehingga untuk meningkatkan volume ekspor perlu dilakukan perbaikan kualitas produk dan perluasan jaringan pemasaran. Pemerintah dapat memberikan penyuluhan sekaliguspendampingan kepada para petani kopi mengenai kualitas kopi yang diminati di mancanegara agar petani dapat meningkatkan kualitas produknya. Dengan adanya peningkatan kualitas, diharapkan komoditas kopi Provinsi Bali dapat memperluas jaringan pemasaran dengan menembus pasar potensial lainnya seperti di negara-negara Eropa. 


\section{Ucapan Terima Kasih}

Ucapan terimakasih ini penulis tunjukan kepada seluruh pihak yang telah membantu dalam pelaksanaan penelitian hingga karya ilmiah ini dapat dipublikasikan di e-jurnal.

\section{Daftar Pustaka}

Basri, faisal. 1995. Perekonomian Indonesia Menjelang Abad XXI. Jakarta Timur: Erlangga Ciracas.

BPS Provinsi Bali. 2010. Bali Dalam Angka 2010. Bali: Badan Pusat Statistik Provinsi Bali.

BPS Provinsi Bali. 2015. Bali Dalam Angka 2015. Bali: Badan Pusat Statistik Provinsi Bali.

BPS Provinsi Bali. 2016. Bali Dalam Angka 2016. Bali: Badan Pusat Statistik Provinsi Bali.

[Ditjenbun] Direktorat Jendral Perkebunan. 2013. Statistik perkebunan Indonesia: Kopi 2013-2015 [online]. Tersedia: ditjenbun.pertanian.go.id. Diakses tanggal 20 oktober 2016.

[Disperindag] Dinas Perindustrian dan Perdagangan Provinsi Bali. 2016. Volume Ekspor dan Nilai Ekspor Kopi provinsi Bali 1996-2015. Bali.

Gujarati, Damodar. 2001. Ekonometrika Dasar. Jakarta: Erlangga

Kartika, Wilda. 2012. Analisis Kontribusi Ekspor Kopi Terhadap PDRB Sektor Perkebunan dan Faktor-faktor yang Mempengaruhi Nilai Ekspor Kopi Sumatera Utara. Program Studi Agribisnis Fakultas Pertanian Universitas Sumatera Utara. Sumatera Utara.

Riadi, edi. 2015. Statistika Penelitian (Analisis Manual dan IBM SPSS). Jakarta: ANDI

Santoso, Singgih. 2009. Panduan Lengkap Menguasai Statistik Dengan SPSS. Jakarta: Salemba Empat. 